Z. Klin. Chem. Klin. Biochem.

13. Jg. 1975 , S. $277-281$

\title{
The Mechanism of the Increase in the Activity of Liver Alkaline Phosphatase in Experimental Cholestasis: Measurement of an Increased Enzyme Concentration by Immunochemical Titration
}

\author{
By R. Schlaeger ${ }^{1}$ ) \\ Abteilung für Klinische Chemie der Medizinischen Universitätsklinik Göttingen
}

(Eingegangen am 13. August 1974)

Summary: Alkaline phosphatase (EC 3.1.3.1) activity increases 5-15 fold in the livers of rats, following bile duct ligation. The mechanism of this increase has been the subject of numerous investigations. In HeLa cells the synthesis of a different phosphatase enzyme protein with higher catalytic activity has been postulated.

After preparing an antiserum against rat liver phosphatase, we compared the phosphatase protein concentration in normal and cholestatic livers by immunochemical titration. Our results clearly indicate that the elevation of enzyme activity is due to an increased accumulation of enzyme protein.

\section{Der Mechanismus des Aktivitätsanstiegs der alkalischen Leberphosphatase bei experimenteller Cholestase: Messung einer erhöhten Enzymkonzentration durch Immuntitration}

Zusammenfassung: Die Aktivität der alkalischen Phosphatase (EC 3.1.3.1) in Rattenleber steigt nach Unterbindung des Gallenganges auf das 5-15fache an. Der Mechanismus des Aktivitätsanstiegs ist trotz zahlreicher Untersuchungen bisher nicht geklärt. In Analogie zu Befunden an HeLa-Zellen wurde postuliert, daß unter der Cholestase ein andersartiges, aktiveres Enzymprotein gebildet wird.

Nach Gewinnung eines Antiserums gegen gereinigte Rattenleberphosphatase verglichen wir mit der Methode der Immuntitration die Phosphatasekonzentration in Kontroll- und Cholestaseleber. Hierfür mußte eine ZweischrittImmunpräzipitationstechnik angewandt werden, da der Antikörper direkt weder präzipitierende noch neutralisierende Wirkung hatte. Unsere Ergebnisse zeigen eindeutig, daß die Zunahme der Enzymak tivität allein auf einer Zunahme der Konzentration des Enzymproteins beruht.

\section{Introduction}

The determination of serum alkaline phosphatase has been used for 40 years as an aid in the diagnosis of cholestatic liver diseases, but the mechanism of the activity increase has not hitherto been elucidated. Experiments on animals have shown that within one day after ligature of the bile duct, the increase in the serum is paralleled by a 10 -fold increase in the specific activity of the liver alkaline phosphatase. This increase can be completely suppressed by inhibitors of protein or nucleic acid synthesis. The dependence of this increase on the integrity of protein synthesis suggests that it is the result of an increased de novo synthesis of enzyme protein. Inhibitor studies must, however, be interpreted with caution. Thus the concept of an activity increase due to the de novo synthesis of a catalytically

1) The results represent part of the Habilitationsschrift of the author. more active enzyme protein was founded by Griffin \& Cox (4) on the basis of their studies on the cortisolinduced increase of phosphatase activity in HeLa cells. Fewerda \& Stepan (5) investigated the rate of incorporation of labelled precursors into partially purified liver phosphatase, and concluded that also in the cholestatic liver of the rat, a more active phosphatase protein is formed, which is different from that normally present.

On the other hand Righetti \& Kaplan (6) have shown recently essentially identical properties of the phosphatase from control and cholestatic liver. Our own studies have indicated, too, complete identity of the two phosphatases in respect of their physicochemical and kinetic behaviour (7).

It appeared that immunological methods would be necessary to give a definitive answer to the question of whether more enzyme, or a different enzyme with greater catalytic activity is produced in cholestasis. 
Having obtained a suitable antiserum against rat liver phosphatase, it was then possible to determine the concentration of the specifically precipitated phosphatase protein in normal and cholestatic liver by immunochemical titration.

\section{Materials and Methods}

Male Wistar-AF rats (Zentralinstitut für Versuchstierzucht, Hannover-Linden) weighing 200-220 g were used.

The animals were kept in a light controlled and air conditioned room. They received the standard animal food Altromin (Altrogge, Lage/Lippe) and water ad libitum.

The antiserum was produced in albino rabbits (New Zealand) weighing $3-4 \mathrm{~kg}$.

All reagents were reagent grade from $\mathrm{E}$. Merck, Darmstadt, with the following exceptions: Acrylamide and N'N-methylenebisacrylamide (Cyanogum 41), and dimethylaminopropionitrile (Cyanogum 41 catalyst) were from Serva, Heidelberg. Complete Freund's adjuvant was from Difco, Detroit, U.S.A. Antirabbit r-globulin serum from goat was from Behringwerke, Marburg.

Phosphatase activity was measured kinetically at $25^{\circ} \mathrm{C}$ with continuous tracing of the change in absorbance in a photometer Eppendorf with an automatic cuvette positioner and recorder (Netheler und Hinz, Hamburg).

Polyacrylamide gel electrophoresis was performed in tubes measuring $5 \times 100 \mathrm{~mm}$, with the aid of the apparatus supplied by the firm of Boskamp, Hersel.

\section{Bile duct ligation}

The bile duct was ligated under ether anaesthesia by the standard procedure.

After 24 hours the rats were bled by heart puncture and the livers removed. Untreated animals served as control. For all experiments the rats were fasted 16 hours prior to the operation and until sacrificed.

\section{Purification of liver alkaline phosphatase}

The partial purification of the alkaline phosphatase was based on the procedure reported by Morton ( 9 ) for bovine liver, and modified by Engström (8). Details and results of the procedure are to be found in l.c. (7). 25 cholestatic and 25 control livers were subjected to $n$-butanol, acetone and ethanol fractionation resulting in a 110 fold purification for both experimental groups. All immunoprecipitation experiments were performed with these two phosphatase preparations with specific activities of $780 \mathrm{U} / \mathrm{g}$ protein and $9800 \mathrm{U} / \mathrm{g}$ respectively.

For immunization of the rabbits, the phosphatase from cholestatic liver was further purified by analy tical polyacrylamide gel electrophoresis (7) ( $7.5 \%$ separation gel (Cy anogum), trisborate buffer $40 \mathrm{mmol} / \mathrm{l}, \mathrm{pH} 8.8 ; 150 \mathrm{~min}, 2 \mathrm{~mA} /$ tube; quantity applied: $75 \mu \mathrm{g}$ protein). This resulted in a further $6-10$ fold purification as estimated from parallel protein (Coomassie blue) and phosphatase staining (glycine buffer pH 10, $\alpha$-naphthyl phosphate, Variamine blue salt B). Following l.c. (10), the phosphatase-positive disc gel section was used as the antigen: After electrophoresis, the phosphatase band was localized by brief incubation in dilute $p$-nitrophenyl phosphate-buffer mixture, then cut out. The sections of approximately $3 \mathrm{~mm}$ were stored at $-20^{\circ}$.

\section{Preparation of antiphosphatase serum}

4 gel sections ( $=2,5 \mathrm{U}$ phosphatase) were suspended in $0.5 \mathrm{ml}$ physiological $\mathrm{NaCl}$ solution by repeated ejection through a fine cannula. This suspension was mixed with complete Freund's adjuvant and injected one rabbit at 6 different sites, right and left of the vertebral column in the dorsal skin. This was repeated after 2 and 4 weeks. 8 days after the last injection blood was taken from the ear vein.
All the preparations of rabbit sera produced a precipitate after 2 days incubation $\left(1\right.$ hour at $37^{\circ} \mathrm{C}$, then 48 hours at $4^{\circ} \mathrm{C}$ ) with the phosphatase preparation from both the colestatic liver and the control liver, but the alkaline phosphatase activity remained unaltered in the $12000 \mathrm{~g}$ supernatant. A second incubation of the supernatant with antirabbit- $\gamma$-globulin serum according to the method of Sussman (10) neither precipitated nor neutralized the phosphatase.

One of the rabbits, treated as described above, was given a booster injection after 6 months. This consisted of $0.4 \mathrm{mg}$ of a phosphatase preparation from cholestatic liver (specific activity $20000 \mathrm{U} / \mathrm{g}$ protein) which had been purified on Sephadex G 200 (column $3 \times 100 \mathrm{~cm}$; elution buffer Tris/ $\mathrm{HCl}$, pH $8,0.1 \mathrm{~mol} / 1, \mathrm{NaCl} 1 \mathrm{~mol} / \mathrm{l})$. Serum taken 8 days later contained antibodies against liver phosphatase, as shown by the double precipitation method.

\section{Analy tical Methods}

Alkaline phosphatase (EC 3.1.3.1) was measured by the optimized standard test (11), final concentrations: diethanolamine buffer $\mathrm{pH} 9.8,1 \mathrm{~mol} / 1, \mathrm{MgCl}_{2} 0.5 \mathrm{mmol} / 1$, p-nitrophenylphosphate $10 \mathrm{mmol} / 1$. This method, as optimized for human serum, was also found to be optimal for rat serum.

Protein was measured by the biuret method, low concentrations were measured by the method of Lowry (12). Bovine albumin (Behring Werke) was used as standard.

For details of the double precipation technique and the immunochemical titration see Results and legends to the figures.

\section{Results}

A marked precipitate was produced when phosphatase preparations were incubated with antiserum for 1 hour

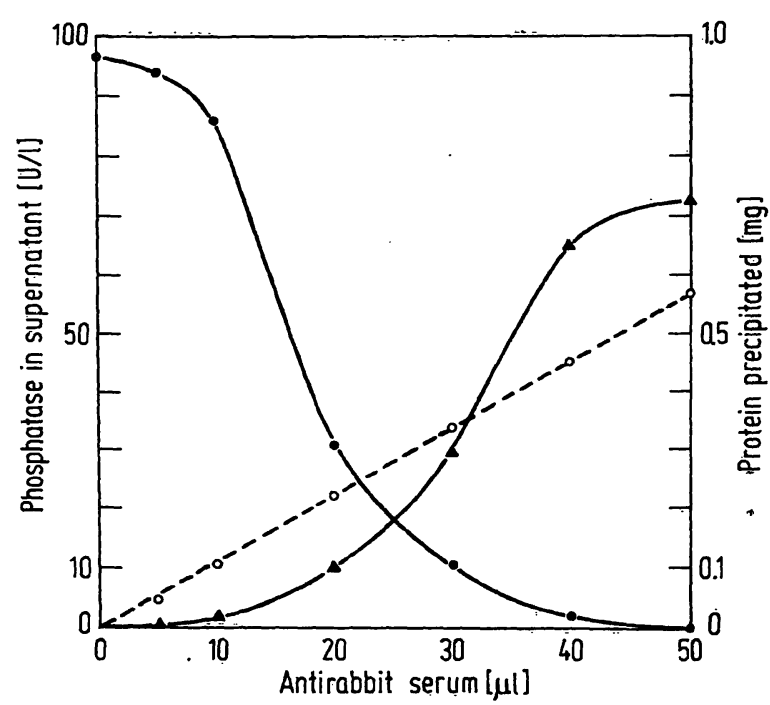

Fig. 1. Determination of the optimal quantity of antirabbit $\gamma$ globulin serum from the goat required for the precipitation of the phosphatase-antibody complex.

1st Step: incubation of $290 \mathrm{mU}$ phosphatase with $20 \mu \mathrm{l}$ rabbit serum in a total volume of $1 \mathrm{ml} \mathrm{NaCl} ; 1 \mathrm{~h}$ at $37^{\circ} \mathrm{C}$, then $48 \mathrm{~h}$ at $4^{\circ} \mathrm{C}$, then centrifugation for $5 \mathrm{~min}$ at $12000 \mathrm{~g}$.

2nd Step: $20 \mu l$ supernatant + goat serum, total volume $70 \mu \mathrm{l}$; incubation $1 \mathrm{~h}$ at $37^{\circ} \mathrm{C}$, then $24 \mathrm{~h}$ at $4^{\circ} \mathrm{C}$. Residual activity measured in the $12000 \mathrm{~g}$ supernatant. Results presented after subtraction of the phosphatase activity of the goat serum. Protein concentration in the precipitate measured after washing with $\mathrm{NaCl}$

- - phosphatase activity in the supernatant after subtraction of the goat serum phosphatase

- - - 0 phosphatase activity in the goat serum

protein in the immunoprecipitate 
at $37^{\circ} \mathrm{C}$ and finally 48 hours at $4^{\circ} \mathrm{C}$. After centrifugation for 5 minutes at $12000 \mathrm{~g}$, the phosphatase activity in the supernatant was, however, the same as that in parallel controls performed with serum from a nonimmunized rabbit or with $\mathrm{NaCl}$. The soluble phosphataseantibody complex was then precipitated by the addition of an antirabbit $\gamma$-globulin serum from goat. The ratio of rabbit serum to goat serum is critical, and this was strictly standardized in preliminary experiments.

Figure 1 shows the immunotitration curve for the determination of the optimal concentration of goat serum.

In the first step liver phosphatase was incubated with $20 \mu \mathrm{l}$ rabbit serum in $0.9 \% \mathrm{NaCl}$ in a total volume of $1 \mathrm{ml}$ (see legend to Fig. 1). $20 \mu \mathrm{l}$ aliquots of the supernatant (concentration of rabbit serum $2 \%$ ) were incubated with increasing volumes of goat serum. After centrifugation, the remaining phosphatase activity in the supernatant and the protein concentration in the precipitate were measured. Since the goat serum also contained a phosphatase activity of $68 \mathrm{U} / 1$, the goat phosphatase activity added to each incubation mixture (dotted line) was subtracted for the determination of the rat liver phosphatase. As shown in the figure, the

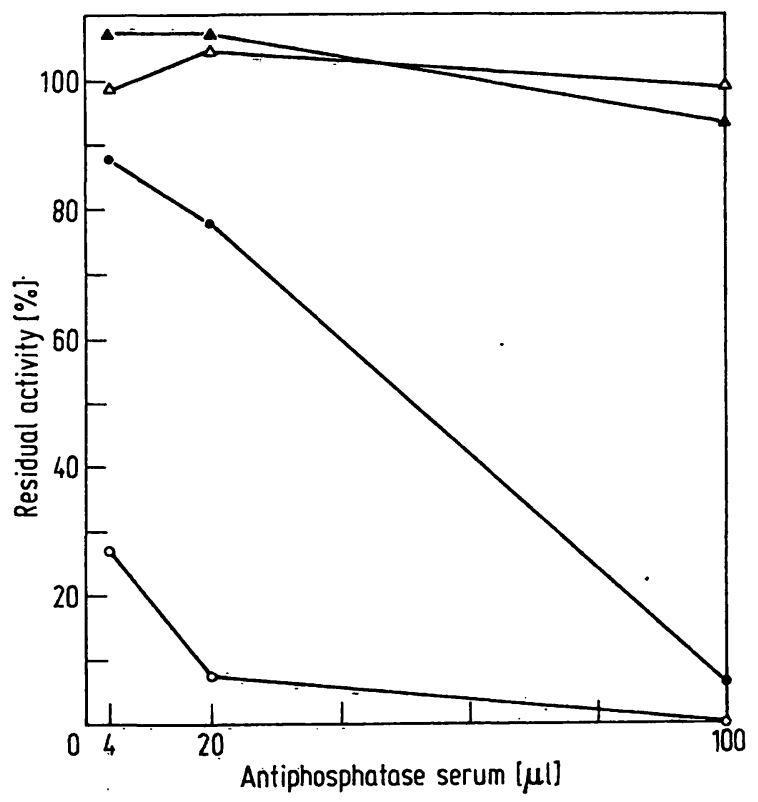

Fig. 2. Immune precipitation of partially purified alkaline phosphatase from control $(0-0, \Delta-\Delta)$ and cholestatic liver $(\bullet-\bullet, \wedge)$ with inçreasing quantities of antiserum.

$100 \mu \mathrm{l}$ phosphatase preparation (control $810 \mathrm{U} / 1$, specific activity $780 \mathrm{U} / \mathrm{g}$ protcin, cholestatic liver $14500 \mathrm{U} / \mathrm{l}$, specific activity $9800 \mathrm{U} / \mathrm{g}$ protein) were incubated with rabbit serum in a total volume of $0.2 \mathrm{ml}$. After $1 \mathrm{~h}$ at $37^{\circ} \mathrm{C}$ and $48 \mathrm{~h}$ at $4^{\circ} \mathrm{C}$, the $12000 \mathrm{~g}$ supernatants were adjusted to a final concentration of $2 \%$ rabbit serum. In the second step, $20 \mu \mathrm{l}$ of this solution were incubated with $50 \mu \mathrm{l}$ goat serum. After centrifugation at $12000 \mathrm{~g}$, the \% phosphatase activity in the supernatant was corrected for dilution and by subtracting the activity added with the goat serum. The upper curves ( $\Delta$ and $\Delta$ ) show the activities in the supernatants of control incubations with serum from a non-immunized rabbit. equivalence point is at $40 \mu \mathrm{l}$ goat serum. On the basis of this determination, the following constant ratio was chosen for the second step: $20 \mu$ rabbit serum diluted 1:50 with physiological $\mathrm{NaCl}$ solution $+50 \mu \mathrm{l}$ undiluted goat serum.

The decisive question was whether a given quantity of antiserum will precipitate all the phosphatase activity from equal volumes of control and cholestatic phosphatase, in spite of the 12.5 fold higher specific activity of the cholestatic preparation. This would be the case if there is an unchanged quantity of enzyme, which has been activated 12.5 fold. Figure 2 shows, however, that a much greater quantity of antiserum is required for the immunoprecipitation of $100 \mu$ partially purified phosphatase from cholestatic liver (for details see legend) than for the precipitation of $100 \mu \mathrm{l}$ of the control preparation.

The figure also shows the specificity of the reaction: identical incubations with the serum of a non-immunized rabbit gave no precipitation, thereby excluding the possibility of unspecific coprecipitation during the second precipitation step.

For a more exact determination of the quantitative relationship, increasing volumes of phosphatase pre-

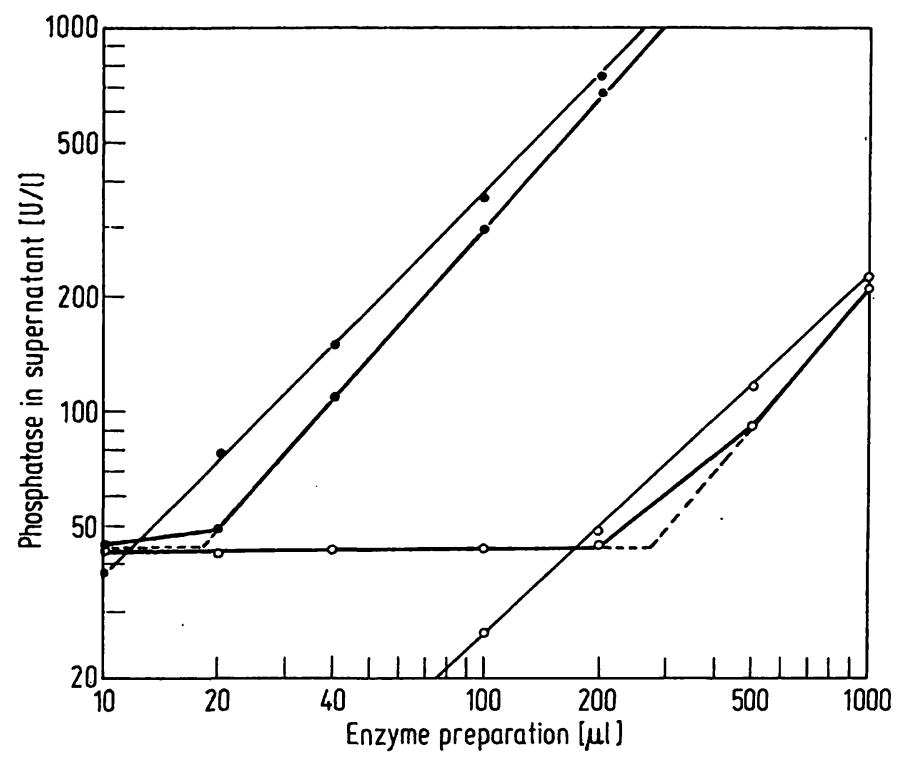

Fig. 3. Immunotitration of partially purified liver phosphatase against a constant quantity of antiserum.

Incubation mixture: $20 \mu$ antiscrum + phosphatase prcparation (control $810 \mathrm{U} / 1$, cholestatic $14500 \mathrm{U} / \mathrm{l}$ ) $+\mathrm{NaCl}$ to $1 \mathrm{ml}$ total volume. Incubation for $1 \mathrm{~h}$ at $37^{\circ} \mathrm{C}$ and $48 \mathrm{~h}$ at $4^{\circ} \mathrm{C}$. For the 2 nd step see legend to Fig. 1 . Results are presented on a double logarithmic scale.

Abscissa: $\mu$ l phosphatase preparation in incubation mixture.

Ordinate: $U / 1$ phosphatase activity in the supernatant (including that of the goat serum phosphatase of $45 \mathrm{U} / 1$ ).

○-o phosphatase from control liver

- phosphatase from cholestatic liver

○—o and - enzyme activities in control incubations with $\mathrm{NaCl}$ in place of goat scrum. 
paration were added to standard quantities of rabbit serum (see Fig. 3). $20 \mu$ l antiserum precipitated the phosphatase from more than $200 \mu$ l of the control preparation, but it was only just sufficient for the complete neutralization of $20 \mu \mathrm{l}$ of the cholestatic preparation. The equivalence points were estimated by extrapolation: $270 \mu \mathrm{l}$ control preparation containing $220 \mathrm{mU}$ phosphatase activity are approximately equivalent to $18 \mu \mathrm{l}$ cholestatic preparation containing 260 $\mathrm{mU}$ activity. Thus, any given quantity of antiserum precipitates the same amount of phosphatase activity, irrespective of whether the phosphatase is derived from control or cholestatic liver.

This finding is confirmed by a different experiment (Fig. 4), in which identical enzyme activities from control and cholestatic liver were titrated against a constant volume of antiserum. In accordance with the higher specific phosphatase activity in the cholestatic liver preparation $(9800 \mathrm{U} / \mathrm{g}$ protein compared with $780 \mathrm{U} / \mathrm{g}$ ), the latter was required in a smaller quantity. In the incubation with the cholestatic preparation, the liver protein concentration was consequently only $8 \%$ of that in the control incubation. Nevertheless, the equivalence points are in very good agreement at 260-270 mU phosphatase per $20 \mu \mathrm{l}$ antiserum.

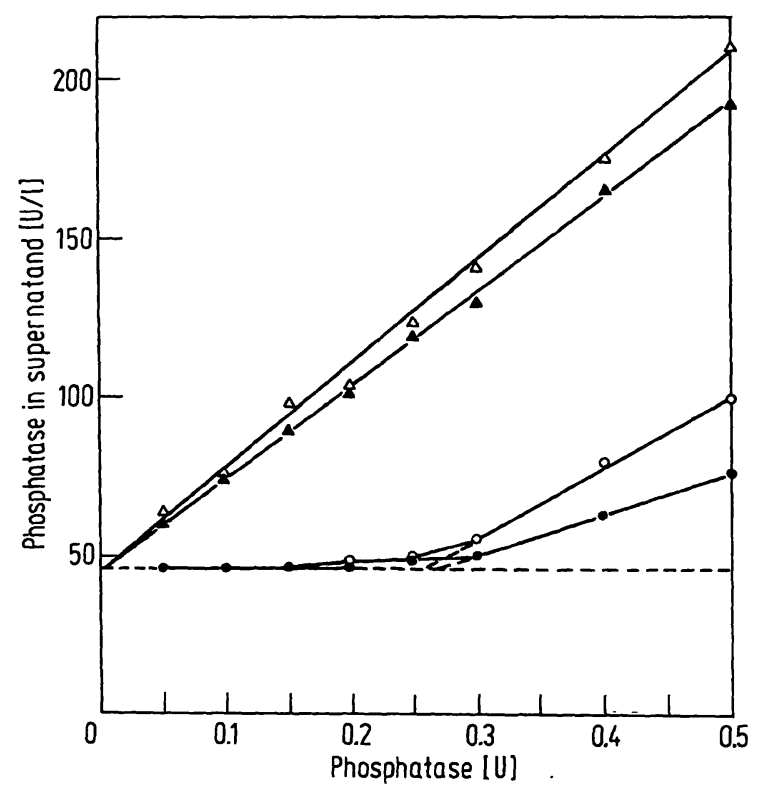

Fig. 4. Immunochemical titration of purified liver phosphatase against constant quantities of antiserum.

For the titration, the same enzyme activities of control and cholestatic liver enzyme preparations were used. The incubation with cholestatic liver phosphatase thus contained a 12.6 fold higher specific activity and only $8 \%$ of the concentration of liver protein present in the control incubation.

Incubations were performed as described in legend to Fig. 3.

○_— control liver phosphatase $\bullet-\bullet$ cholestatic liver phosphatase

$\triangle \longrightarrow \Delta$ and $\Delta-\Delta$ identical incubations with serum from a nonimmunized rabbit. The horizontal dotted line represents the phosphatase activity of the
goat serum.

\section{Discussion}

Unequivocal proof that de novo synthesis is responsible for the increase in activity of alkaline phosphatase in liver was hitherto lacking. By analogy with the findings of Cox and his group $(4,13)$, it has always been considered possible that a different catalytically more active phosphatase protein is formed in the liver. In HeLa cell cultures, 1-4 days after the addition of cortisol, these authors showed a 5-20 fold increase in the specific activity, which could be inhibited by puromycin. Using an antiserum against HeLa cell phosphatase, they showed that the antibody concentration required for the precipitation of a certain base level activity would also precipitate the 5 fold activity of cortisol-induced phosphatase, yet the protein content of the two precipitates was the same. The hormone-induced enzyme differed from the basal enzyme in many physicochemical.properties, such as temperature stability and behaviour on Sephadex G 200. In 1971, the authors confirmed their findings and postulated the production of a modifier molecule responsible for the higher specific activity of the induced phosphatase (13). It was suggested that a change in the specific binding of zinc at the catalytic centre of the phosphatase was responsible for the alteration in activity.

Comparable studies on liver phosphatase were hitherto not possible owing to the lack of a suitable antiserum. On the basis of studies on the incorporation of labelled amino acids into purified phosphatase, Fewerda \& Stepan (5) supported the hypothesis of a catalytically activated enzyme in cholestatic liver: After 1000 fold purification, the specific ${ }^{14} \mathrm{C}$-activity was the same in the alkaline phosphatase from control and cholestatic liver. According to the authors, this shows that there is no increased synthesis of enzyme protein. Against this interpretation is the fact that even a thousand fold purification is not sufficient to resolve this question. Engström (8) reported a 40000 fold purification from bovine liver. According to this, if a similar specific " activity is assumed for bovine and rat liver, then the thousand fold purified rat liver phosphatase still contains about $98 \%$ foreign protein. In our opinion, a 3-10 fold increase in the ${ }^{14} \mathrm{C}$-activity of the $2 \%$ of phosphatase protein would be undetectable against the background of general protein labelling.

After initial difficulties, we finally succeeded in producing in one rabbit, a suitable antibody against rat liver phosphatase. However, it was not possible to perform a direct reaction between the antigen and antibody, because the antiserum neither neutralized nor precipitated the liver phosphatase.

Using the method described by Sussman (10) for their antibody against human liver phosphatase', a second immune reaction with an antirabbit $\gamma$-globulin from the goat was used to precipitate the soluble antigen- 
antibody complex. After the standardization of this second step, it was possible to perform a reliable immunochemical titration.

Our results show that the quantity of antiserum for complete precipitation depends only on the phosphatase activity, irrespective of whether the alkaline phosphatase is from control or cholestatic liver. The titration curves of increasing phosphatase activity against constant quantities of antiserum give identical equivalence points for purified phosphatase from control and cholestatic liver. This proves unequivocally that cholestatic liver simply contains more of the alkaline phosphatase enzyme protein.

\section{References}

1. Börnig, H., Horn, A. \& Müller, W. (1969), Acta Biol. Med. Ger. 22, 537-549.

2. Börnig, H., Stepan, J., Horn, A. \& Giertler, R. (1967), Hoppe-Seyler's Z. Physiol. Chem. 348, 1311-1318.

3. Kaplan, M. M. \& Righetti, A. (1970), J. Clin. Invest. 49, 508-516.

4. Griffin, M. J. \& Cox, R. P. (1966), Proc. Nat. Acad. Sci. USA. 56, 946-953.

5. Fewerda, W. \& Stepan, J. (1973), Hoppe-Seyler's Z. Physiol. Chem. 354, 1462-1472.

6. Righetti, A. \& Kaplan, M. M. (1974), Proc. Soc. Exp. Biol. Med. $145,726-728$.
The theory of a different catalytically more active phosphatase protein after bile duct ligation must now be rejected. The elevated phosphatase activity in cholestatic liver is due exclusively to an increased concentration of the enzyme protein.

\section{Acknowledgements}

This investigation was supported by funds from the Deutschen Forschungsgemeinschaft.

I am grateful to Miss H. v. Seydlitz and Miss W. Grashorn for their reliable technical assistance.
7. Schlaeger, R. \& Zech, R. (1975), Clin. Chim. Acta, in prep.

8. Engström, L. (1964), Biochim. Biophys. Acta 92, 71-78.

9. Morton, R. K. (1958), Biochem. J. 57, 595-603.

10. Sussman, H. H., Small, P. A. \& Cotlove, E. (1968), J. Biol. Chem. 243, 160-166.

11. Empfehlungen der Deutschen Gesellschaft f. Klin. Chemie (1972), this j. 10, 182-192.

12. Lowry, O. H., Rosebrough, N. J., Farr, A. L. \& Randall, R. J. (1951), J. Biol. Chem. 193, 265-275.

13. Cox, R. P., Elson, N. E., Tu, S. H. \& Griffin, M. J. (1971), J. Mol. Biol. 58, 197-215.

Priv. Doz. Dr. R. Schlacger Medizin. Klinik, Abtlg. Klin. Chem.

Humbold tallee 1

D-3400 Göttingen 
